\title{
Production and Technique in the Iron and Steel Industry in Japan during 1971
}

\section{By Tsuneyo $I K I^{*}$}

\section{Introduction}

A rapid expansion of the Japanese economy since the latter half of 1960's has been manifested in its growth rate which registered continuously over $15 \%$. By 1970, however, there began to rise voices of worries over the future of the Japanese economy. Around the summer of the same year, economic conditions began to proceed to the direction of serenity and immobility. For nearly one year the receding phase has not ceased. This retreat in the Japanese economy has been gradually created by the factors described as follows: (1) the aftereffects of up valuation of the official yen rate to $6.25 \%$ and the policy of tight economy; (2) the measures taken on September 1 in 1969 to regulate the excess supply of goods which was brought through continuous large scale capital investments in equipment; (3) the retardation trend in production and shipment of goods followed by the increase in stock and decrease in the equipment investment since June in 1970. Such trends began to appear as a consequence of decreased demand for lasting consumer goods partly influenced by consumers' campaign. Reflecting foregoing regressive symptoms in the national economy and the advance of shipment schedule in anticipation of a possible strike by the U.S. harbor workers, the amount of exports showed a tendency of increase until Summer of 1970 while the growth rate of the imports was hampered due to the retardation in domestic production activities. The unbalance in exports and imports brought the temporary growth of profit in the country's international income and expenditure. As President Nixon announced his new economic policy on August 15 including the termination of dollargold exchange system and adoption of the surcharge on imports duties, international financial conditions became significantly unstable and the in-flow of foreign currency in the form of investment was enhanced.

With the appearance of these new situations, Japanese Government has striven to solve the currency problem by switching its fixed yen-rate policy to a fluctuating market system. This issue is expected to remain as a major problem. Instability in the field of foreign exchange gave a serious blow to the country's export transactions. Together with the domestic problems, this set-back in exports has resulted in financial depression for the first time since 1965.

It became apparent that economic prospects of the country in 1971 would be much lower than the earlier estimate. Nominal growth rate of the economy is expected to fall down sharply to the $5.5 \%$ level in stead of the $10.1 \%$ level as estimated at the beginning of the year.

Effects of the depression were deeply felt by the iron and steel industries. Particularly, reflecting the decreased capital investment in equipment by the private sector, steel consumption by major users such as construction, industrial and electrical machinery industries decreased in a larger scale than in 1970. Steel industries has attempted to control the amount of stock which began to pile up in the previous year. Total amount of crude steel produced in the period from January to September in 1971 would amount to 65960000 tons. This figure indicates $6.1 \%$ decrease over the corresponding period of the previous year.

The efforts to control the amount of stock began to hamper the growth rate since last May. The Japanese Government announced a policy to promote economic activities by financial and fiscal measures. It was expected in the steel industry that by the latter half of 1971, the domestic demand would reach to the lowest point and that the economy would turn out to be more favourable thereafter.

However, the new economic policy of the United States announced on August 15 brought the surcharge on imported steel goods, and forced Japanese Government to adopt the fluctuating market system. The new situations brought further decrease in the exports by steel consuming industries and their postponement of equipment investment. Consequently, the demand for steel in the latter half of 1971 would be much lower than initially estimated.

Regardless of depressive market conditions, the international exchanges have been active in all fields, particularly in the technology and science of steel industries.

For example, in April and October, the 12th and 13th periodical conferences between Japanese Government and European Coal and Steel Community (ECSC) were held respectively. At the fall conference there were active exchanges of opinions on the unstable international economy as exemplified in U.S. surcharges on imports.

In March, the Inauguration Meeting of Southeast Asia Iron and Steel Institute was held in Singapore. It is expected that future activities of this Institute would contribute greatly to the development of the iron and steel industries in the area.

Looking at domestic factors, in December, 1970

\footnotetext{
* Chief Secretary, the Joint Research Society, The Iron and Steel Institute of Japan, Chiyoda-ku, Tokyo 100.
} 
Table 1. Production of pig irons, crude

\begin{tabular}{|c|c|c|c|c|c|c|}
\hline & Item & $\begin{array}{l}1968 \\
\text { Total }\end{array}$ & $\begin{array}{l}1969 \\
\text { Total }\end{array}$ & $\begin{array}{l}1970 \\
\text { Total }\end{array}$ & $\begin{array}{l}1971 \\
\text { Jan. }\end{array}$ & $\begin{array}{l}1971 \\
\text { Feb. }\end{array}$ \\
\hline \multicolumn{2}{|c|}{ Blast furnace pig iron } & 45952 & 57650 & 67539 & 6072 & 5596 \\
\hline \multicolumn{2}{|c|}{ Crude steel } & 66893 & 82166 & 93271 & 7491 & 7103 \\
\hline \multicolumn{2}{|c|}{ Hot rolled plain carbon steel (general) } & 49477 & 59343 & 67292 & 5282 & 5042 \\
\hline \multirow{6}{*}{$\begin{array}{l}\text { Major } \\
\text { hot rolled } \\
\text { steel }\end{array}$} & Medium sections & 1443 & 1605 & 1720 & 134 & 140 \\
\hline & Small bars & 6315 & 6745 & 7289 & 613 & 628 \\
\hline & Ordinary wire rods & 2136 & 2261 & 2402 & 196 & 190 \\
\hline & Heavy \& medium plates & 9628 & 11447 & 14184 & 1185 & 1165 \\
\hline & Sheets & 748 & 908 & 928 & 65 & 67 \\
\hline & Wide strip & 19878 & 24837 & 28189 & 2086 & 1927 \\
\hline \multicolumn{2}{|c|}{ Hot rolled special steel } & 5178 & 6577 & 7382 & 569 & 581 \\
\hline
\end{tabular}

the Diet passed a resolution to revise and strengthen bills concerning environmental pollution. The ministerial ordinances relating to these laws were enacted in June, 1971. Pursuant to these new laws, various new standards of public environment were established and power of regulating public hazards was transferred to prefectural authorities to a large extent. Further in July, the Government established Environment Agency for the purpose of preserving natural environment and other desirable living environment and promoting long term and powerful measures against public hazards.

Various characteristics of the Japanese iron and steel technology are reviewed in the following.

\section{Production, Demand, and Exports}

The iron and steel industries received a serious blow by production reduction measures extended for a longer period due to the recession of the economy since 1970 and following the August announcement of new U.S. economic policy. In the industrial circle there rose voices desiring a erude steel cartel to improve the depression created by the decreased production. In November an application for such a cartel was submitted to the Fair Trade Commission together with that for a stainless steel cartel. Accordingly the regressive trend of the industrial activities was enhanced further. Thus the crude steel production in 1971 is estimated to be much lower than that of 1970, 93320000 tons. Actual production through January to September in 1971 recorded 6.1\% decrease compared with that in the comparable period of the previous year as above described. This trend of decreasing production would likely continue in the near future. The change in output of blast furnace pig iron, crude steel, and steel products are shown in Table 1 .

Looking back the blast furnace operation, three blast furnaces constructed last year commenced operations. They are No. 1 furnace of Kashima Works of Sumitomo Metal Industry (in January), No. 4 furnace of Fukuyama Works of Nippon Kokan (April), and No. 3 furnace of Kimitsu Works of Nippon
Steel Corp. (September). In addition, two furnaces in June and the one more in August resumed operations after completing repairs. The classification of the crude steel output by the type of furnaces reveals that the ratio of converter steel to the total steel output continued to increase in 1971 attaining more than $80 \%$ in comparison with $79.1 \%$ in the previous year. An output of open hearth furnace steel showed a decrease again in 1971 and its ratio to the total output fell down to 2 from $4.1 \%$ in the previous year. The ratio of electric arc furnace steel showed a slight increase above the previous year's $16.8 \%$ and is estimated to reach $17 \%$ in 1971 . In relation to hot rolled steel products, the output in 1971 would likely be less than the previous one by $7 \%$ for ordinary steel and $6 \%$ for special steel.

The trend in demand and supply of iron and steel in 1971 showed cooling of zeal in equipment investment in the private sector reflecting the slow-down of general economic growth which started in 1970. Construction, industrial machinery, and electrical machinery industries, which are major steel consumers, did not show a larger demand than in the previous year. The amount of shipment of ordinary rolled steel products during the first half of 1971 was 29990 000 tons which was $7.6 \%$ decrease from a comparable figure of the preceding year.

Consequently the stock of steel products increased greatly. Steel makers made efforts to carry production activities according to the current demand and to control the amount of stock by cutting down the crude steel output. However the adjustment in this aspect did not work successfully. Such factors mentioned above and inactive market conditions gave rise to opinions which favor the production reduction as a whole.

Until mid 1971 the steel exports continued to grow favourably in spite of depressive features in the domestic economy. This fact owed to an advance purchase by the U.S. to prepare for an outbreak of a strike in the iron and steel industries and to the advance date of export schedule in anticipation of a dock strike in the United States. It is also due to the completion 
steels, and steel products (unit : $1000 \mathrm{t}$ )

\begin{tabular}{|c|c|c|c|c|c|c|c|}
\hline $\begin{array}{l}1971 \\
\text { Mar. }\end{array}$ & $\begin{array}{l}1971 \\
\text { Apr. }\end{array}$ & $\begin{array}{l}1971 \\
\text { May }\end{array}$ & $\begin{array}{l}1971 \\
\text { June }\end{array}$ & $\begin{array}{l}1971 \\
\text { July }\end{array}$ & $\begin{array}{l}1971 \\
\text { Aug. }\end{array}$ & $\begin{array}{l}1971 \\
\text { Sept.* }\end{array}$ & $\begin{array}{c}1971 \\
\text { Jan.-Sept. Total }\end{array}$ \\
\hline 6186 & 5786 & 6099 & 5766 & 5972 & 6140 & 6260 & 53877 \\
\hline 7630 & 7094 & 7330 & 7044 & 7273 & 7445 & 7548 & 65958 \\
\hline 5353 & 4890 & 5057 & 4985 & 5309 & 5547 & 5603 & 47068 \\
\hline 138 & 132 & 142 & 149 & 144 & 129 & 150 & 1258 \\
\hline 620 & 565 & 586 & 609 & 629 & 606 & 630 & 5486 \\
\hline 207 & 212 & 214 & 208 & 184 & 191 & 113 & 1715 \\
\hline 1239 & 1087 & 1122 & 1088 & 1102 & 1142 & 1178 & 10303 \\
\hline 69 & 63 & 61 & 55 & 55 & 55 & 57 & 547 \\
\hline 2192 & 1942 & 2036 & 1997 & 2239 & 2437 & 2380 & 19236 \\
\hline 602 & 577 & 571 & 593 & 588 & 571 & 583 & 5235 \\
\hline
\end{tabular}

* Provisional figure

of stock adjustment efforts in Europe and to the decrease in exports of the United States toward other countries.

However, the prospects of exports for the latter half of 1971 are not bright, since the exports toward the United States should be diminished due to selfimposed restrictions. This means that the large exports in the first half period would have to be compensated with reduced exports in the second half. In addition, the import surcharges to be placed by the United States, and direct and indirect effects of the adoption of the fluctuating market system have significant influence on the export of steel.

It is also expected that the output of special steels would be less than the previous year. The output of hot rolled steel products in 1971 is estimated approximately as 7000000 tons with 400000 tons decrease from the previous year.

\section{Technology}

\section{General Review}

The iron and steel industry is the one which requires large scale equipment and accumulated technology. The former is very effective to improve efficiency of iron and steel production but, in turn, it requires the most advanced techniques. The Japanese iron and steel technology has been developed together with the economic growth of the country. Having experienced the period of absorbing foreign technology introduced from European and American countries, the country has become one of the most developed iron and steel kingdoms from technological aspects. This change is clearly observed in the trend that technological imports once flourished is gradually ceasing and on the other hand technological exports are increasing.

\section{Ironmaking Technology}

In the field of pre-treatment of blast furnace raw materials, there are trends for increasing automation and enlargement of equipment size. Since Japan depends $95 \%$ of its supply of raw materials on imports from foreign resources, a method for reducing steel price is to cut-down a transportation cost of these materials by using ultra-large carriers. In order to harbor giant ore carriers whose size are ever increasing, the piers of iron and steel works are not only enlarged but also equipped with sea berth as in the case of Oita Works of Nippon Steel Corp. The sea berth of this works is equipped with 2 belt conveyors which automatically carry ores unloaded from giant carriers of 60000 to 250000 tons class. In addition, pre-treatment process of iron ores has been strengthened recently for the purpose of securing efficient blast furnace operations. New methods were introduced in connection with crushing and sizing of the iron ores and a computer control method is increasingly employed in the charging process of blast furnaces. Increase in tapping rate and lowering of coke ratio have been achieved by charging the improved raw materials, moisture addition, oxygen enrichment, fuel injection, hot blast, and high pressure operations.

These technological achievements in the country and the fact that the country is known for having a blast furnace with the largest inner volume in the world have fully made the country as one of the most technologically advanced nations.

Oxygen injection to giant size blast furnaces increased oxygen consumption by the industries. In October, at Mizushima Works of Kawasaki Steel, the largest oxygen plant in Japan was constructed with capability of producing $103000 \mathrm{Nm}^{3}$ oxygen per hour. The other works, including Fukuyama Works of Nippon Kokan, also have large equipment for oxygen production. Many of the recent blast furnaces employ a furnace body cooling by Steeve cooling method which is known to contribute to the extension of a furnace life. Active researches are underway to develop furnace body cooling method which is a decisive factor in determining a repairing period of blast furnaces. This problem, incidentally, was selected as a subject of discussion by Joint Research Society of The Iron and Steel Institute of Japan.

As described in Table 2, blast furnace operations in 
Table 2. Blast furnace performance

\begin{tabular}{|c|c|c|c|c|c|c|c|c|c|}
\hline Item & $\begin{array}{c}1969 \\
\text { Average }\end{array}$ & $\begin{array}{c}1970 \\
\text { Average }\end{array}$ & $\begin{array}{l}1971 \\
\text { Jan. }\end{array}$ & $\begin{array}{l}1971 \\
\text { Feb. }\end{array}$ & $\begin{array}{l}1971 \\
\text { Mar. }\end{array}$ & $\begin{array}{l}1971 \\
\text { Apr. }\end{array}$ & $\begin{array}{l}1971 \\
\text { May }\end{array}$ & $\begin{array}{l}1971 \\
\text { June }\end{array}$ & $\begin{array}{l}1971 \\
\text { July }\end{array}$ \\
\hline Ore ratio & 1.56 & 1.58 & 1.59 & 1.60 & 1.60 & 1.60 & 1.60 & 1.61 & 1.61 \\
\hline Coke ratio (average) & 493 & 475 & 457 & 450 & 441 & 449 & 447 & 450 & 445 \\
\hline Coke ratio (lowest per furnace) & 432 & 405 & 384 & 366 & 369 & 362 & 377 & 376 & 387 \\
\hline $\begin{array}{l}\text { Sintered ore consumption ratio } \\
\text { (pellet included) }(\%)\end{array}$ & 75.2 & 76.5 & 78.2 & 78.0 & 77.9 & 80.8 & 80.9 & 81.3 & 80.3 \\
\hline Pig iron output ratio & 1.73 & 1.95 & 1.89 & 1.89 & 1.91 & 1.87 & 1.86 & 1.81 & 1.81 \\
\hline
\end{tabular}

Table 3. Converter operation performance

\begin{tabular}{|c|c|c|c|c|c|c|c|c|c|}
\hline Item & $\begin{array}{c}1969 \\
\text { Average }\end{array}$ & $\begin{array}{c}1970 \\
\text { Average }\end{array}$ & $\begin{array}{l}1971 \\
\text { Jan. }\end{array}$ & $\begin{array}{l}1971 \\
\text { Feb. }\end{array}$ & $\begin{array}{l}1971 \\
\text { Mar. }\end{array}$ & $\begin{array}{l}1971 \\
\text { Apr. }\end{array}$ & $\begin{array}{l}1971 \\
\text { May }\end{array}$ & $\begin{array}{l}1971 \\
\text { June }\end{array}$ & $\begin{array}{l}1971 \\
\text { July }\end{array}$ \\
\hline $\begin{array}{l}\text { Steel production per hour of } \\
\text { operation }(t)\end{array}$ & 196.6 & 210.3 & 204.9 & 207.4 & 206.1 & 203.9 & 203.7 & 204.5 & 202.7 \\
\hline $\begin{array}{l}\text { Production of sound ingots per hour } \\
\text { of direct labor }(\mathrm{kg} / \mathrm{hr})\end{array}$ & 2938 & 3186 & 3007 & 3050 & 2971 & 2792 & 2826 & 2710 & 2827 \\
\hline Seelmaking time per change $(\mathrm{min} / \mathrm{ch})$ & 35 & 35 & 36 & 35 & 35 & 36 & 36 & 36 & 36 \\
\hline Unit consumption of oxygen $\left(\mathrm{Nm}^{3} / \mathrm{t}\right)$ & 51.6 & 51.2 & 50.5 & 50.7 & 50.3 & 50.7 & 51.7 & 50.5 & 50.9 \\
\hline Pig iron ratio $(\%)$ & 80.3 & 80.2 & 85.8 & 85.6 & 87.4 & 87.8 & 88.7 & 88.8 & 87.9 \\
\hline Hot metal ratio $(\%)$ & 75.9 & 77.3 & 85.2 & 84.7 & 86.5 & 86.9 & 87.5 & 87.3 & 86.9 \\
\hline
\end{tabular}

Table 4. Open hearth furnace operation performance

\begin{tabular}{|c|c|c|c|c|c|c|c|c|c|}
\hline Item & $\begin{array}{c}1969 \\
\text { Average }\end{array}$ & $\begin{array}{c}1970 \\
\text { Average }\end{array}$ & $\begin{array}{l}1971 \\
\text { Jan. }\end{array}$ & $\begin{array}{l}1971 \\
\text { Feb. }\end{array}$ & $\begin{array}{l}1971 \\
\text { Mar. }\end{array}$ & $\begin{array}{l}1971 \\
\text { Apr. }\end{array}$ & $\begin{array}{l}1971 \\
\text { May }\end{array}$ & $\begin{array}{l}1971 \\
\text { June }\end{array}$ & $\begin{array}{l}1971 \\
\text { July }\end{array}$ \\
\hline $\begin{array}{l}\text { Production of sound ingot per hour } \\
\text { of operation }(t / h r)\end{array}$ & 16.0 & 15.2 & 13.6 & 13.9 & 13.9 & 13.7 & 14.3 & 13.9 & 14.1 \\
\hline Pig iron ratio $(\%)$ & 48.6 & 41.8 & 35.8 & 37.5 & 37.5 & 34.5 & 35.3 & 34.2 & 36.4 \\
\hline $\begin{array}{l}\text { Production of sound ingot per hour } \\
\text { of direct labor }(\mathrm{kg} / \mathrm{hr})\end{array}$ & 599 & 567 & 508 & 462 & 521 & 477 & 471 & 478 & 478 \\
\hline $\begin{array}{l}\text { Calorie consumption per ton of sound } \\
\text { ingot }\left(10^{3} \mathrm{kcal} / \mathrm{t}\right)\end{array}$ & 887 & 956 & 1034 & 971 & 953 & 1006 & 972 & 948 & 977 \\
\hline
\end{tabular}

1971 did not record a notable decrease in coke ratio or improvement in tapping rate. This is due to the reduced amount of tapping as a consequence of the depression. However, a full employment of presently available technology could certainly accomplish higher efficiency operations.

Among 3 blast furnaces constructed during 1971, No. 4 furnace of Fukuyama Works of Nippon Kokan is the largest one in the world having the inner volume of $4197 \mathrm{~m}^{3}$, and daily tapping capacity of 10000 tons. This furnace is also the first in the world with the inner volume exceeding $4000 \mathrm{~m}^{3}$ with floor diameter of $13.8 \mathrm{~m}, 97 \mathrm{~m}$ height, two casting floors, three tapping holes and 40 tuyeres. It can be operated under ultra high pressure of $2.5 \mathrm{~kg} / \mathrm{cm}^{2}$ at furnace top. The high efficiency operation of this blast furnace is possible by making use of a 4 bell system which is employed to secure uniform distribution of charging materials and to strengthen gas seal, facilities for heavy oil injection, oxygen enrichment, and hot blast.

No. 3 furnace of Kimitsu Works of Nippon Steel Corp., completed 5 months after Fukuyama's, is the second largest in the world with the inner volume of $4063 \mathrm{~m}^{3}$. It has 4 tapping holes, the first of the kind in Japan, a floor diameter of $13.4 \mathrm{~m}$ and 35 tuyeres. With its ultra high pressure operation at $2.5 \mathrm{~kg} / \mathrm{cm}^{2}$ at furnace top, hot blast at $1300^{\circ} \mathrm{C}$, and $100 \% \mathrm{em}$ - ployment of sintered ore are designed to achieve the largest daily output in the world.

No. 1 of Kashima Works of Sumitomo Metal is also an extremely large blast furnace with $3159 \mathrm{~m}^{3}$ inner volume. It is equipped with most advanced facilities such as raw material distributing equipment at the furnace top and high pressure operations. Its torpedo car is able to receive 400 tons of pig iron and is the largest of the kind in the country.

\section{Steelmaking Technology}

As of July, 1970, 84 converters were operating in the country and in 1971 three new converters began operations. In May, 1971 one of the world's largest converters with production ability over 300 tons per charge was completed at Oita Works of Nippon Steel Corp. Thus in the field of converters, there is a tendency for large size furnaces as in the field of blast furnaces Table 3 shows converter operation performances.

Production per hour for steelmaking would certainly be diminished below 210.3 tons, the average of 1970, reflecting the decrease in crude steel production. This is not a matter of technology but rather the necessity led by the current demand. The ratio of killed steel to total steel production is increased again in 1971 and exceeded 30\%. This fact reveals 
Table 5. Electric furnace operation performance

\begin{tabular}{|c|c|c|c|c|c|c|c|c|c|}
\hline \multicolumn{2}{|l|}{ Item } & $\begin{array}{c}1969 \\
\text { Average }\end{array}$ & $\begin{array}{l}1970 \\
\text { Average }\end{array}$ & $\begin{array}{l}1971 \\
\text { Jan. }\end{array}$ & $\begin{array}{l}1971 \\
\text { Feb. }\end{array}$ & $\begin{array}{l}1971 \\
\text { Mar. }\end{array}$ & $\begin{array}{l}1971 \\
\text { Apr. }\end{array}$ & $\begin{array}{l}1971 \\
\text { May }\end{array}$ & $\begin{array}{l}1971 \\
\text { June }\end{array}$ \\
\hline \multirow{2}{*}{$\begin{array}{l}\text { Production of sound ingot per } \\
\text { hour of performance ( } \mathrm{t} / \mathrm{hr})\end{array}$} & For special steel & 7.6 & 8.1 & 8.4 & 8.5 & 8.7 & 8.7 & 8.8 & 8.8 \\
\hline & Total & 8.9 & 9.2 & 9.5 & 9.5 & 9.8 & 10.0 & 10.2 & 10.2 \\
\hline \multirow{2}{*}{$\begin{array}{l}\text { Oxygen consumption per ton } \\
\left(\mathrm{Nm}^{3} / \mathrm{t}\right)\end{array}$} & For special steel & 13.2 & 16.6 & 16.1 & 17.1 & 16.9 & 16.2 & 16.1 & 15.6 \\
\hline & Total & 14.3 & 16.9 & 16.4 & 17.0 & 16.9 & 16.4 & 16.4 & 15.5 \\
\hline \multirow{3}{*}{ Pig iron ratio $(\%)$} & For special steel & 4.9 & 6.0 & 5.7 & 5.0 & 5.3 & 5.7 & 5.4 & 6.0 \\
\hline & For plain carbon steel & 0.6 & 0.5 & 0.6 & 1.5 & 1.3 & 0.7 & 1.3 & 1.1 \\
\hline & Total & 3.0 & 3.8 & 3.7 & 3.6 & 3.7 & 3.7 & 3.6 & 3.9 \\
\hline \multirow{2}{*}{$\begin{array}{l}\text { Sound ingot production per } \\
\text { hour of direct labor }(\mathrm{kg} / \mathrm{hr})\end{array}$} & For special steel & 415 & 450 & 455 & 446 & 446 & 431 & 430 & 437 \\
\hline & Total & 452 & 469 & 484 & 477 & 483 & 461 & 469 & 474 \\
\hline \multirow{3}{*}{$\begin{array}{l}\text { Electric power consumption } \\
\text { per ton }(\mathrm{kWh} / \mathrm{t})\end{array}$} & For special steel & 538 & 576 & 582 & 582 & 586 & 583 & 595 & 583 \\
\hline & For plain carbon steel & 486 & 549 & 558 & 553 & 544 & 550 & 546 & 553 \\
\hline & Total & 516 & 566 & 571 & 571 & 569 & 570 & 574 & 571 \\
\hline
\end{tabular}

that refining operations by converters are increasing. Another characteristic feature of 1971 is increased molten iron mixing ratio which exceeded $85 \%$ indicating the over stock of pig iron and also the effects of the depression.

Open hearth furnace operation performance is shown in Table 4. Decreasing popularity of open hearth furnace continued in 1971 and as of the end of August there were 66 furnaces installed in the country. Among blast furnace makers the only one producing with open hearth furnace is Nakayama Steel Works. Consequently, the pig iron mixing ratio was lower than that of the previous year and fell below $40 \%$.

Electric arc furnace operation performance is given in Table 5. According to the table, per hour output of good steel ingot for both special and carbon steels showed a tendency of increase.

Positive efforts have been made in the field of continuous casting equipment. As of July in 1971, the number of continuous casting equipment in the country was 51 and the annual productivity was 16668000 tons which made the country the first rank in the world in this field surpassing the USSR, (estimated annual productivity : 12000000 tons), the top ranking nation in the past. In addition, there are 14 furnaces being constructed. The combined annual productivity by the end of 1971 would likely exceed 20000000 tons. As for technology and equipment in this field of steelmaking, a slab conveyor by on-line method has been developed for carrying continuously cast slab and is actually employed at Fukuyama Works of Nippon Kokan. The equipment at this works was developed for the purpose of transporting slabs efficiently and quickly. Such a process became desirable due to the improvements in continuous casting techniques such as increased speed of continuous casting and easy shifting of slab sizes. Incidentally, Fukuyama Works is planning to produce 3000000 tons of crude steel out of its annual output of 12000000 tons with the continuous casting mill.

Along with new techniques developed in the continuous casting, significant improvements were made in the field of degassing. Especially for the production of high quality alloy steels, degassing facilities using various methods such as fluid degassing, DH degassing, RH degassing, ladle degassing, and vacuum decarburization method of stainless steel, are increasingly installed as necessary facilities.

\section{Rolling Technology and Others}

In the field of rolling, enlargement of rolling mill and automation are being promoted. An equipment for a full-scale continuous production of steel plates was installed at No. 2 cold tandem mill of Fukuyama Works of Nippon Kokan. The process with new equipment is to roll cast steel continuously by welding coils prior to rolling rather than stopping operations for each coil and of passing a succeeding coil at a lower speed. In connection with the new equipment new techniques such as changing plate thickness in rolling, automatic tracing of welded parts, shearing of strips at the exit side of the rolling mill, selection of coiling roll, and automatic coil binding were developed.

With respect to a hot strip mill, developments of AGT equipment and rapid roll changing equipment have been considered and methods to assure continuity with boundary processes are examined. Concerning a senzimir mill, emphasis was placed on improvements in productivity as indicated in the employment of a tandem mill at Shunan Works of Nisshin Steel Works. Table 6 shows rolling operation performances.

Since the development of new products creates a further demand for steel, the industry has been promoting this aspect positively. For example, Nippon Kokan has successfully developed an $80 \mathrm{~kg} / \mathrm{mm}^{2}$ class high tensile steel plate of as-rolled and normalized type. In comparison with quenched and tempered 
Table 6. Rolling

\begin{tabular}{|c|c|c|c|c|c|}
\hline \multicolumn{2}{|c|}{ Item } & \multirow{2}{*}{$\begin{array}{c}\begin{array}{c}\text { Blooming } \\
\text { (2-high } \\
\text { reversible) }\end{array} \\
352.4\end{array}$} & \multirow{2}{*}{$\begin{array}{c}\begin{array}{c}\text { Blooming } \\
\text { large } \\
\text { sections }\end{array} \\
71.7\end{array}$} & \multirow{2}{*}{$\begin{array}{c}\begin{array}{c}\text { Medium } \\
\text { sections }\end{array} \\
28.7\end{array}$} & \multirow{2}{*}{$\begin{array}{r}\begin{array}{r}\text { Small } \\
\text { sections }\end{array} \\
29.9\end{array}$} \\
\hline \multirow{6}{*}{$\begin{array}{l}\text { Quantity rolled per hour of } \\
\text { rolling operation }(\mathrm{t} / \mathrm{hr})\end{array}$} & 1970 average & & & & \\
\hline & 1971 Jan. & 384.6 & 75.7 & 27.4 & 32.0 \\
\hline & Feb. & 344.3 & 74.0 & 29.6 & 34.9 \\
\hline & Mar. & 352.1 & 66.4 & 28.3 & 31.8 \\
\hline & Apr. & 349.7 & 65.9 & 28.1 & 31.1 \\
\hline & May & 349.4 & 67.8 & 28.6 & 30.2 \\
\hline \multirow{5}{*}{$\begin{array}{l}\text { Calorie consumption per } \\
\text { material ton rolled } \\
\left(10^{3} \mathrm{kcal} / \mathrm{t}\right)\end{array}$} & 1970 average & 211 & 584 & 497 & 476 \\
\hline & 1971 Jan. & 227 & 619 & 579 & 486 \\
\hline & Feb. & 225 & 620 & 558 & 484 \\
\hline & Mar. & 224 & 647 & 576 & 497 \\
\hline & May & 234 & 643 & 555 & 496 \\
\hline \multirow{6}{*}{$\begin{array}{l}\text { Material consumption per } \\
\text { hour of direct labor } \\
(\mathrm{kg} / \mathrm{hr})\end{array}$} & 1970 average & 4663 & 548 & 418 & 548 \\
\hline & 1971 Jan. & 4420 & 514 & 380 & 592 \\
\hline & Feb. & 4359 & 493 & 414 & 632 \\
\hline & Mar. & 4362 & 434 & 387 & 562 \\
\hline & Apr. & 4156 & 436 & 377 & 561 \\
\hline & May & 4199 & 439 & 395 & 597 \\
\hline
\end{tabular}

type steel, this type can be produced in a large quantity by a strip mill. It is expected that this steel plate would meet increasing demands for bridges, structures, and pressure vessels in the future. Kobe Steel Ltd. also succeeded in developing a welding rod with high moisture resistance for high tensile steel. In the past a dry welded rod had to be used in welding high tensile steel for bridges and pressure vessels to prevent the hydrogen entry from a hydroscopic welding rod. The new product made improvements in this aspect and is expected to simplify construction of large size structures.

\section{Technological Exchanges with Foreign Countries and Investments Abroad}

The recovery of the Japanese iron and steel industry in the post-war period was accomplished by the introduction of technology from the Western countries, namely energetic employment of most advanced techniques and construction of new plants. In the past there was an enormous number of foreign techniques introduced. However, the recent development in the Japanese iron and steel technology has enabled the country to transform itself from a technologyimporting country to a technology-exporting country. Today the country's blast furnace technology and converter technology are by no means inferior to international standards and are exported even to European and American countries. In combination with exports of technology in the other fields, they are contributing to the improvement of the international income and expenditure of Japan. In the future, particular considerations must be paid on the qualitative change in exports. The qualitative rather than quantitative perspective would become essential and promotion of trade should not be considered simply from the income and outcome point of view. In the iron and steel industry, the merchandise with qualitative feature, or exports of technology, should be promoted more emphatically. Concerning the number of technological introduction, the scope for automatic validation was enlarged, and liberalization of foreign investment was enhanced together with simplified application procedures in 1971. Technological introductions applied for validation in 1971 are shown in Table 7 (Class A) and Table 8 (Class B). A specifically notable technique in Class $\mathrm{A}$ was the one concerning steam cooling method for blast furnace introduced from the USSR. This method was originally introduced to Nippon Steel Corp. and because of its efficiency in improving cooling effects of furnace body and extending furnace life, both Sumitomo Metal and Kawasaki Steel applied for licenses to utilize the method.

Table 9 shows Japanese investments abroad validated. In the iron and steel industry, the objects of such investments are developing nations in most cases. Quantitatively speaking, except few cases such as Pohang and Usiminas, investments are restricted to the fields of pre-rolling processes. Looking at existing conditions in iron and steel industries of the developing nations, two patterns of the industry are observed. One is the construction of a comprehensive steelmaking plant including processes from blast furnace to rolling and processing while in the other, construction starts with processing plants and extends gradually to iron and steelmaking plants. Between the above-mentioned two patterns the latter contains less risks, and investments from the private sector, apart from those of governmental projects, tend to be directed to the latter. In order to promote further Japanese investments abroad in the future, full 
performance

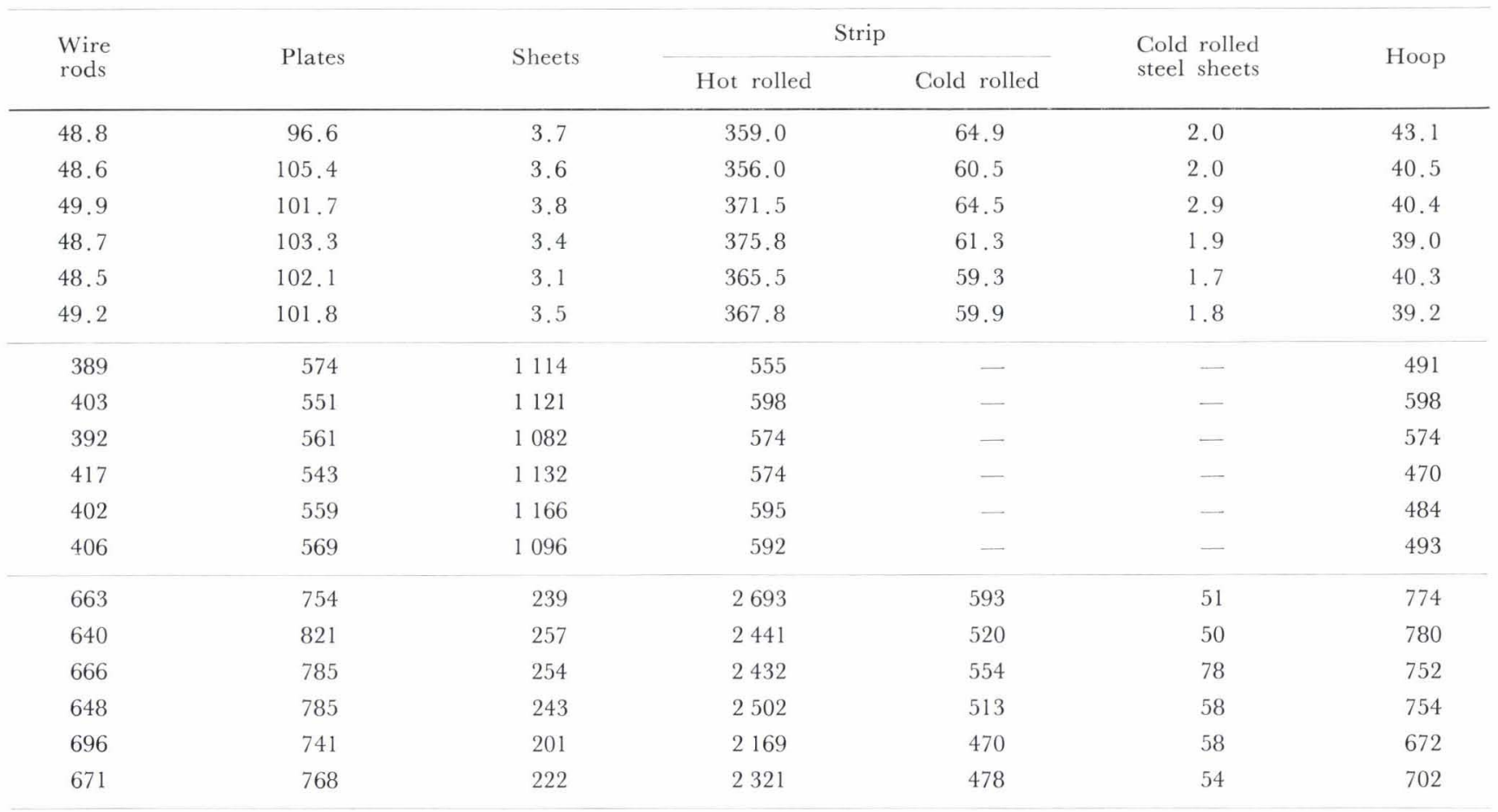

considerations must be made on the harmony between desires of the invested countries and the above-mentioned tendency of the investors.

\section{Japan-Sweden Symposium on Metallurgy}

This symposium was held for two days, namely May 24 (Monday) and 25 (Tuesday), 1971 at Keidanren Kaikan under the sponsorship of our Institute and with cooperation of concerned circles and received an 8 member mission from Sweden headed by Professor S. Eketorp.

The main theme of the symposium was ferrous metallurgy. In addition, there were some lectures related to the problems in education and research in metallurgy. Professor Eketorp and other members of the Swedish team presented 13 papers which were responded by 9 Japanese fapers. One significant feature of the meeting was that lectures and discussions were delivered in English only.

After the symposium the Swedish group made trips to and exchanged opinions with responsible persons at the following places: Tokyo University; Nagoya University; Tohoku University; National Research Institute for Metals; Kimitsu Works, Fundamental Research Laboratory and Product Technology Research Laboratory of Nippon Steel Corp. ; Technology Research Laboratory of Nippon Kokan; Technology Research Laboratory of Kawasaki Steel; Central Research Laboratory of Sumitomo Metal; Central Research Laboratory of Kobe Steel; Aichi Steel Works, and Tokyo Steel Works of Mitsubishi Steel. The team left Japan on June 5.

\section{3rd Japan-USSR Joint Symposium on Physical Chemis- try of Metallurgical Processes}

Japan-USSR Joint Symposium on Physical Chem- istry of Metallurgical Processes has been conducted bi-annually between the Academy of Sciences of USSR and Japan. The 3rd symposium convened last year for three days of September 27 (Monday), 28 (Tuesday), and 29 (Wednesday) in Moscow. The Institute sent an 8 member scientific delegation under the leadership of Professor Mori of Kyoto University.

A major theme of this symposium was mutual reactions of gas and molten steel. The number of papers presented at the meeting was 23 which included 9 Japanese papers and 14 Soviet papers. Fruitful discussions were deliberated. The post-symposium visits were made to seven research laboratories at Tbilist, Kiev, Leningrad, and Moscow. Valuable contributions were rendered for scientific and technological exchanges between the two nations.

\section{Iron and Steel Mission to Northern Europe}

The Institute in the fast sent two missions abroad (United Kingdom; Benelux countries and West Germany). It has been promoting friendly relations with iron and steel circles of the world and has been trying to meet the needs of the international age. As one of these continuous efforts, the Institute sent the Iron and Steel Mission (Leader: Sachio Matoba, total number of members including ladies: 18) to 4 countries of Northern Europe (Norway, Sweden, Finland, and Denmark). The mission cultivated friendly relations with the iron and steel circle in each country through various activities such as receptions, conferences, and visits to works and research institutes.

Leaving Japan on September 7, the mission spent 8 days in Norway, 9 days in Sweden, 3 days in Finland, and 4 days in Denmark and completed the activities as a group in Copenhagen on September 28 where each member set out for independent activities. 
Table 7. Foreign techniques

\begin{tabular}{|c|c|c|c|}
\hline \multicolumn{2}{|c|}{$\begin{array}{c}\text { Date } \\
\text { approved }\end{array}$} & \multirow{2}{*}{$\begin{array}{l}\text { Accepted by } \\
\text { Nippon Kokan K.K. }\end{array}$} & \multirow{2}{*}{$\begin{array}{l}\text { Rendered by } \\
\text { Dr.-Ing Werner Wenzel }\end{array}$} \\
\hline 1971 & 1. 14 & & \\
\hline 1971 & 1. 18 & Toshin Steel Co., Ltd. & Concast A.G. \\
\hline 1971 & 1. 29 & Nippon Steel Corp. & Edelstahlwerke Witten G.m.b.H. \\
\hline 1971 & 2. 25 & Nippon Metal Industry Co., Ltd. & Concast A.G. \\
\hline 1971 & 2. 27 & Nippon Steel Corp. & British Steel Corp. \\
\hline 1971 & 3. 6 & Bridgestone Bekaert Steel Cord Co., Ltd. & N.V. Bekaert SA \\
\hline 1971 & 3. 16 & Nissho Iwai Co., Ltd. & Tadeusz Sendzimir \\
\hline 1971 & 3. 18 & Bridgestone Cycle Industry Co., Ltd. & N.V. Bekaert Engineering SA \\
\hline 1971 & 3. 25 & Wean Japan & Wean United Inc. \\
\hline 1971 & 3. 25 & Wean Japan & Wean United Inc. \\
\hline 1971 & 3. 26 & Wean Japan & Wean United Inc. \\
\hline 1971 & 3. 29 & Wean Japan & Wean United Inc. \\
\hline 1971 & 3. 30 & Keihan Briquetting Industry Co., Ltd. & Didier-Kellogg Industrieanlagenbau GmbH \\
\hline 1971 & 4. 6 & Ochiai Seisakusho, Co., Ltd. & Waldes Kohinoor, Inc. \\
\hline 1971 & 4. 7 & Okura Trading Co., Ltd. & $\begin{array}{l}\text { Societe Anonyme des Anciens Etablissements } \\
\text { Paul Wurth }\end{array}$ \\
\hline 1971 & 4. 9 & Tomoe Kogyo, Co., Ltd. & Union Carbide, Corp. \\
\hline 1971 & 4. 13 & Kobe Steel, Ltd. & Gutehaffnungohütte Sterkrade AG \\
\hline 1971 & 4. 21 & Sumitomo Electric Industries, Ltd. & Gränges Essem $\mathrm{AB}$ \\
\hline 1971 & 4. 28 & C. Itoh \& Co., Ltd. & Hunter Engineering Co., Ltd. \\
\hline 1971 & 5. 8 & Nippon Forming & AMF Thermatool \\
\hline 1971 & 5. 15 & Nippon Kokan K.K. & Dr. C. Otto \& Co. GmbH \\
\hline 1971 & 5. 18 & Mitsubishi Aluminum Co., Ltd. & Reynolds Metals Co. \\
\hline 1971 & 5. 22 & Shinko Pfaudler Co., Ltd. & Sybron Corp. \\
\hline 1971 & 6. 5 & Kyoritsu Kikai Co., Ltd. & The Yoder Company \\
\hline 1971 & 7. 3 & $\begin{array}{l}\text { Nippon Steel Corp. } \\
\text { (Sub-licensee) Kawasaki Steel Corp. }\end{array}$ & $\begin{array}{l}\text { Vsesojuznoje Exportno-Importnoje } \\
\text { Objedinenije "Licensintorg" }\end{array}$ \\
\hline 1971 & 7. 6 & Tokyo Mfg. Co., Ltd. & Concast A.G. \\
\hline 1971 & 7. 6 & Tosa Denki Seikosha, Co., Ltd. & Concast A.G. \\
\hline 1971 & 7. 19 & Haneda Hume Kan Co., Ltd. & Humes Ltd. \\
\hline 1971 & 7. 23 & Nitto Tekko Co., Ltd. & Karl Gerlach \\
\hline 1971 & 8. 13 & $\begin{array}{l}\text { Nippon Steel Corp. } \\
\text { (Sub-licensee) Sumitomo Metal Industries, Ltd. }\end{array}$ & $\begin{array}{l}\text { Vsesojuznoje Exportno-Importnoje } \\
\text { Objedinenije "Licensintorg" }\end{array}$ \\
\hline 1971 & 8. 16 & Otsuka Iron Works, Ltd. & Stedman Foundry \& Machine Co., Inc. \\
\hline 1971 & 9. 2 & Daido Steel Co., Ltd. & Hoesch Aktiengesellschaft \\
\hline 1971 & 9. 16 & Aiko, Co., Ltd. & Burning Bar Sales Company \\
\hline 1971 & 9. 20 & Nippon Kokan K.K. & Pennwalt \\
\hline 1971 & 10. 4 & Daiwa Can, Co. & American Can, Co. \\
\hline 1971 & 10. 25 & Japan U.S.S. Technology Co., Ltd. & U.S.S. Engineers and Consultants Inc. \\
\hline
\end{tabular}

Table 8. Foreign techniques

\begin{tabular}{|c|c|c|}
\hline $\begin{array}{l}\text { Date } \\
\text { approved }\end{array}$ & Accepted by & Rendered by \\
\hline $1971 \quad 2.9$ & Wean Japan & Wean United Inc. \\
\hline $1971 \quad 5.6$ & Chiyoda Kako Kensetsu Co., Ltd. & Ruthner Industrieplanungs, AG \\
\hline 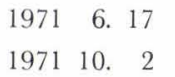 & $\begin{array}{l}\text { Aoyama Seisakusho Co., Ltd. } \\
\text { Wean Japan }\end{array}$ & $\begin{array}{l}\text { Russel Burtsel \& Word Bolts \& Nuts } \\
\text { Wean United Inc. }\end{array}$ \\
\hline
\end{tabular}

This kind of mission makes an important contribution to the promotion of friendship between Japan and other nations under such circumstances that critical attitudes are rising against the Japanese iron and steel 
introduced in 1971 (Class A)

\begin{tabular}{|c|c|}
\hline Nationality & Technique \\
\hline West Germany & Blast furnace technique and related techniques \\
\hline Switzerland & Operation technique of continuous casting equipment by Rossi method \\
\hline West Germany & Vacuum decarburization refining method of stainless steel \\
\hline Switzerland & Operation technique of fully-curved Concast type continuous casting facilities \\
\hline U.K. & Techniques concerning non-destructive testing instrument \\
\hline Belgium & Manufacturing technique of steel code for tires and rubber products for industrial use \\
\hline U.S.A. & Technique concerning construction and use of Sendzimir planetary hot rolling mill \\
\hline Belgium & Manufacturing technique of machinery to produce steel codes \\
\hline U.S.A. & Designing and manufacturing technique of coil preparation facilities \\
\hline U.S.A. & Designing and manufacturing technique of electrolytic cleaning facilities \\
\hline U.S.A. & Designing and manufacturing technique of oxygen washing facilities \\
\hline U.S.A. & Designing and manufacturing technique of oxygen washing facilities \\
\hline West Germany & Designing, construction, operation, and knowhow of vertical open-end type coke oven \\
\hline U.S.A. & Acquisition of industrial property right (license to practice) within Japan concerning self locking ring \\
\hline Luxemburg & $\begin{array}{l}\text { Designing, manufacturing, installing, and operation techniques of blast furnace, parts and auxiliary facilities } \\
\text { in the present and future }\end{array}$ \\
\hline U.S.A. & $\begin{array}{l}\text { Method of lowering carbon contents of chromium bearing steel and patented technology concerning bath- } \\
\text { bottom tuyere used to practice this method }\end{array}$ \\
\hline West Germany & Manufacturing technique of adjustable throat armor \\
\hline Sweden & Manufacturing technique of automatic coiler of rough drawn wires \\
\hline U.S.A. & $\begin{array}{l}\text { Manufacturing technique of rolling mill, leveller, and pent line for non-ferrous and steelmaking } \\
\text { purposes }\end{array}$ \\
\hline U.S.A. & Manufacturing technique of shape steel for structural uses by high frequency wave welding \\
\hline West Germany & Technique concerning construction of the 4 th coke oven group at Fukuyama Works of Nippon Kokan \\
\hline U.S.A. & Technique concerning flaxless vacuum hard soldering \\
\hline U.S.A. & $\begin{array}{l}\text { Manufacturing technique of glass lining machine and its auxiliary parts, stainless steel products, hi-nickel } \\
\text { products and anti-acid alloy metal products, palmchit products (including application techniques of reverse } \\
\text { osmotic module) and DCG sludge concentrator }\end{array}$ \\
\hline U.S.A. & $\begin{array}{l}\text { Designing and manufacturing technique concerning welded pipe manufacturing facilities, cold role shaping } \\
\text { machine, cutter, slitter, and other machineries manufactured by Jorder Co. }\end{array}$ \\
\hline U.S.S.R. & Technique concerning steam cooling and water cooling of blast furnace \\
\hline Switzerland & Operation technique of continuous casting equipment by Rossi method \\
\hline Switzerland & Operation technique of continuous casting equipment by Rossi method \\
\hline Australia & $\begin{array}{l}\text { Manufacturing technique of Humes continuous iron basket welding machine and manufacturing technique } \\
\text { of iron basket used in manufacturing process of Humes pipes }\end{array}$ \\
\hline West Germany & Manufacturing technique of iron beam and Kcuppe for mine drifts \\
\hline U.S.S.R. & Technique concerning steam cooling and water cooling of blast furnace \\
\hline U.S.A. & Manufacturing technique concerning multi-cage type crusher \\
\hline West Germany & Manufacturing technique of calcium drilling steel \\
\hline U.S.A. & Manufacturing technique of rod for disjointing iron and steel, rock, and concrete \\
\hline U.S.A. & Technique concerning surface treatment of metal products with solution mainly consisting of chromium acid \\
\hline U.S.A. & $\begin{array}{l}\text { Manufacturing technique of metal containers and composite containers (including manufacturing technique } \\
\text { of plugger and winding machine for production of containers) }\end{array}$ \\
\hline U.S.A. & $\begin{array}{l}\text { Designing, manufacturing, installation, and operation techniques of sliding gate and pouring pipe to control } \\
\text { flow of molten metal from bottom pouring type container }\end{array}$ \\
\hline
\end{tabular}

introduced in 1971 (Class B)

Nationality

Technique

\begin{tabular}{l|l}
$\begin{array}{l}\text { U.S.A. } \\
\text { Austria }\end{array}$ & $\begin{array}{l}\text { Designing and manufacturing technique of hot rolled plate shearing machine } \\
\text { Technique concerning recovery of hydrochloric acid from wastes of oxygen washing with Lusky hydrochloric } \\
\text { acid recovery method for the facilities at Tetsugen (at Tobata Works of Nippon Steel) }\end{array}$ \\
$\begin{array}{l}\text { U.S.A. } \\
\text { Manufacturing technique of tensi-lock with selfbinding screw }\end{array}$ \\
U.S.A. & Designing and manufacturing technique of continuous zinc plating facilities delivered Kawatetsu Kohan
\end{tabular}

industries which are growing to be a powerful industry in the world.

\section{Environmental Problem}

The Diet session at the end of 1970 decided to 
Table 9. Japanese

\begin{tabular}{|c|c|c|}
\hline $\begin{array}{c}\text { Date } \\
\text { accepted }\end{array}$ & Applicant & Overseas partners \\
\hline $1971 \quad$ 1. 9 & Shinko Shoji Kaisha Ltd. & The Shinsho American Corp. \\
\hline $1971 \quad 2 . \quad 9$ & Sumitomo Metal Industries, Ltd. & Western Tube \& Conduct Corp. \\
\hline $1971 \quad 2.12$ & Nakai Shoten Co., Ltd. & Toyo Suzuita Kogyo Co., Ltd. \\
\hline $1971 \quad 3.22$ & Marubeni-Iida Co., Ltd. & Kowa Kogyo Co., Ltd. \\
\hline $1971 \quad 3.22$ & Marubeni-Iida Co., Ltd. & Sanyo Tokuko Co., Ltd. \\
\hline $1971 \quad 4.21$ & $\begin{array}{l}\text { Nissho Iwai, Co., Ltd.; } \\
\text { Kasuga Kogyo, Co., Ltd. }\end{array}$ & P.T. Iron Wire Works Indonesia \\
\hline $1971 \quad 6.7$ & Hanwa Kogyo, Co., Ltd. & Hanwa (Hongkong) \\
\hline $1971 \quad 6.7$ & Kanjiso & Hiyama Kogyo Co., Ltd. \\
\hline $1971 \quad 6.23$ & Tokyo Boeki Inc. & Tokyo Boeki Inc. \\
\hline $1971 \quad 7.9$ & Kawasaki Steel, Corp. & Lamigal C.A. \\
\hline $1971 \quad 7.12$ & Taisei Tekkosho, Co., Ltd. & Taisei Juko, Co., Ltd. \\
\hline $1971 \quad 7.14$ & Sumitomo Metal Industries, Ltd. & Western Tube \& Conduct of Los Angeles, Inc. \\
\hline $1971 \quad 7.15$ & Tokyo Boeki Inc. & Tokyo Boeki PTY Ltd. \\
\hline 19718. & Mitsui \& Co., Ltd. & Mitsui \& Co. Espania S.A. \\
\hline $1971 \quad 8.10$ & Nippon Steel Corp. & Empreedimentos Brasileiros de Mineracao S.A. \\
\hline 19718.20 & $\begin{array}{l}\text { Pacific Trading Co., Ltd.; } \\
\text { Osaka Sliter Kogyo Co., Ltd. }\end{array}$ & Pacific Metal Industry Son Berhad \\
\hline 19718.26 & Shinko Tetsuryoku Insatsu Kojo Ltd. & Shinko Inka Tetsu Seikansho \\
\hline $19719 . \quad 2$ & Sumitomo Metal Industries, Ltd. & Western Tube \& Conduct Corp. \\
\hline
\end{tabular}

amend the existing laws and establish the new ones relating to environmental pollution which has become a great national concern in recent years. Basic principles contained in these laws are : (1) the priority will be placed on favourable living conditions; (2) the regulatory power will be transferred to prefectural authorities; and (3) the detail regulatory actions will be taken against environmental pollution.

The iron and steel industry has been concerned with the public hazards issue seriously and regarding it as a very important lasting problem. It has been taking decisive measures such as change of plant location, development of air pollution prevention techniques, and investigation of existing conditions. Concerning the preventive techniques, there is an example of study on desulfurization and smoke elimination for sintering plant. The most critical problem of air pollution in the industry is sulfur dioxide, a major part of which is created by the sintering process. Nine makers having blast furnace led by The Iron and Steel Institute of Japan has been conducting experiments on smoke elimination and desulfurization techniques. Such joint efforts would enable to complete an equipment to eliminate $150000 \mathrm{Nm}^{3} / \mathrm{H}$ smoke by the end of 1971.

The amount of investment made for anti-pollution facilities is increasing considerably every year indicating the industry's concern over the subject.

In last July the Environment Agency was established in order to unify public hazards administration and to promote the anti-pollution measures.

\section{Equipment}

The equipment investment in 1971 by the industries were characterized by the apparent increase in the pollution related construction and by the small scale investment in general production facilities as manifested in the postponement of blast furnace construction. Thus the general investment in production facilities would be less than initially estimated.

According to equipment investment plans investigated in February in 1971 the industries as a whole was to spend 919800 million yen on construction basis. The figure showed $10.7 \%$ increase rate, half of the previous year's increase rate of $25.3 \%$. Looking at the figures of each division of the industries, the ordinary steel division planned for 809400 million yen investment with $12.8 \%$ increase over the previous year for construction of blast furnace and anti-pollution measures. The increase rate in this division is less than half of the previous one while in special steel division, reflecting effects of unfavourable market conditions for stainless steel, investment of 59500 million yen at increase rate of $1.0 \%$ lower than that of the previous year was planned. In ferro-alloy division, investment of 39200 million yen at $1.1 \%$ lower increase rate in comparison with the previous one was scheduled.

Major facilities completed in 1971 are described in the following.

Three new blast furnaces were constructed in the ironmaking division. They are No. 1 blast furnace at Kashima Works of Sumitomo Metal (inner furnace volume: $3159 \mathrm{~m}^{3}$ ) completed in April, No. 4 at Fukuyama Works of Nippon Kokan (inner furnace volume: $4197 \mathrm{~m}^{3}$ ) completed in January, and No. 3 of Kimitsu Works of Nippon Steel (inner furnace volume: $4063 \mathrm{~m}^{3}$ ) completed in September. In addition, No. 5 blast furnace of Chiba Works of Kawasaki Steel (inner furnace volume: $2584 \mathrm{~m}^{3}$ ), No. 1 of Wakayama Works of Sumitomo Metal (inner furnace volume : $1633 \mathrm{~m}^{3}$ ), No. 2 of Fukuyama Works (inner furnace volume: $2828 \mathrm{~m}^{3}$ ) and No. 4 of Doko Works (inner furnace volume: $1540 \mathrm{~m}^{3}$ ) of Nippon 
investments abroad in 1971

\begin{tabular}{|c|c|c|}
\hline Nationality & Activities & $\begin{array}{c}\text { Applicant's } \\
\text { capital share } \\
(\%)\end{array}$ \\
\hline U.S.A. & Export and sale of iron and steel products and non-ferrous metal products and machineries & 100 \\
\hline U.S.A. & Processing and sale of pipes & 60 \\
\hline R.O.K. & Manufacturing of tin galvanized plates & 47.37 \\
\hline R.O.K. & Processing of iron beams & 49 \\
\hline R.O.K. & Manufacturing of stainless cold rolled plates & 49 \\
\hline Indonesia & Manufacturing, processing, and sale of iron wires & 60 \\
\hline Hongkong & Export, import, and domestic sale & 100 \\
\hline R.O.K. & Manufacturing and sale of dark surface nats for steel products & 40 \\
\hline U.S.A. & Export and import of steel materials & 100 \\
\hline Venezuela & Manufacturing and sale of zinc plates & 46.08 \\
\hline R.O.K. & Exports of iron beams, bridges, cans, cranes, etc. & 80 \\
\hline Australia & Export and import of steel products and ferro-manganese & 100 \\
\hline Spain & Export, import, and domestic sale & 100 \\
\hline Brazil & Investment corporation toward MBR, a mine development corporation & 20 \\
\hline Malaysia & Processing of plates and manufacturing and sale of steel bands & 35 \\
\hline Hongkong & Joint venture on metal plate printing and can-production & 50 \\
\hline U.S.A. & Processing and sale of pipes & 60 \\
\hline
\end{tabular}

Steel were respectively repaired to resume operations. No. 2 of Doko and No. 1 of Muroran of Nippon Steel and No. 2 of Fukuyama of Nippon Kokan stopped operations. As a result there were 63 blast furnaces in operation in the country (as of August).

In the steelmaking division, 2 converters (250 t/ charge) at Kashima Works of Sumitomo Metal, 1 converter (250 t/charge) at Fukuyama Works of Nippon Kokan, and 2 converters (300 t/charge) at Kimitsu Works of Nippon Steel were respectively constructed in January, April, and September. Consequently the number of converters in the country reached 88 . As for open hearth furnaces, the number decreased to 27 from 46 in the previous year.

Concerning the continuous casting facilities, a Concast type at Mizushima Works and Chiba Works of Kawasaki Steel, a Concast type at Wakayama Works of Sumitomo Metal, a Mannessmann type at Shunan Works of Nisshin Steel, and a Mannessmann type at Fukuyama Works of Nippon Kokan were respectively completed in January, June, January, April, March, and May. Combining other new constructions completed, the continuous casting facilities in the country totaled 51 (as of July) with the world's top raking productivity of 16000000 tons.

In the rolling division, a hot strip mill and a cold tandem mill were completed at Fukuyama Works of Nippon Kokan. The cold tandem mill is the world's first full-scale continuous type.

A hot strip mill was completed in September at Oita Works of Nippon Steel while at Kimitsu Works of the same firm, a slabbing mill and a rod mill were constructed in connection with the No. 3 blast furnace. Further, in September, a galvanizing line to produce the thickest zinc coating in the country was completed at Fukuyama Works of Nippon Kokan.

The significant features in the construction of facilities in 1971 were pointed out in the above. Reflecting the recession in the Japanese economy, many industries had to alter their initial long-term equipment plan to a considerable extent.

\section{Activities of Various Research Societies}

\section{Joint Research Society}

The Joint Research Society has been conducting energetic research activities related to iron and steel technology in its 13 divisions and 21 subdivisions. Major activities of these divisions and subdivisions are reviewed in the following.

\section{i. Ironmaking Division}

The Ironmaking Division holds two meetings annually. In 1971, " Charging of Large Quantity Heavy Oil for the Purpose of Lowering Coke Ratio ", "Relations between Properties and Characteristics of Sintered Ore and Blast Furnace Conditions ", and "Problems and Measures concerning Facilities and Operation of High Temperature Blast " were selected as common research themes and active discussions were also carried on special lectures and papers on other themes.

Coke Subdivision, a subsidiary organization in the division, held two meetings. Discussions were deliberated on common themes of " Properties of Coke for Blast Furnace ", "Automation and Mechanization in Coke Oven ", " Dust Measuring Method for Coke Oven ", "Measures for Lowering the Cost of Material Coal", and "Measures for Dust and Waste Liquid at Coke Plant and Processing Plant'. A trend which did not appear in previous years was that there were many studies related to environmental pollution within the division as well as in the subdivision.

\section{ii. Steelmaking Division}

In addition to the activities of the division itself, 
Mold and Electric Arc Furnace Subdivisions are promoting useful studies. The division held 3 meetings in which the active exchange of ideas and views proceeded on steelmaking facilities such as measuring techniques in steelmaking, raw materials for and operations of steelmaking, ingotmaking, degassing, continuous casting, and economical use of power. The division also conducted a serious study on a newly selected subject, namely " public hazards". A special lecture was delivered at its 50th anniversary meeting.

The Mold Subdivision custommarily holds 3 meetings for paper presentation in 2 years. In the current term, studies and discussions were exchanged on material properties, manufacturing techniques, designing techniques, management and repairing techniques of mold, and mold board and foreign source information. The subdivision composed "List of Present Status of Mold and Mold Board Usage" and "Survey Results on Mold Designing and Management".

The Electric Arc Furnace Subdivision held two research meetings to discuss high power operations of electric arc furnace, measures for major raw materials, a method of component analysis in front of furnace and machinery. Since last year "Measures for Public Hazards " became a new theme. Studies were made on the relations between major raw materials and dust composition, the present status of dust collector, noise preventive measures, the treatment of wastes and flicker.

\section{iii. Special Steel Division}

In the past the division used to hold three meetings annually. In order to enrich the contents of each meeting, the frequency of the meeting was reduced to twice in 1971. The division selected "Study on Quality and Manufacturing Techniques of Special Steel" as a common theme and placed a special emphasis on the the following subthemes; the quality of continuously cast steel; the special melting refining method; the special ingot-making method; the improvement in arc furnace efficiency; the improvement in techniques and economical use of power in production processes; deoxidization and its products using complex deoxidizing agents; the relations between properties of materials for special steel and metallurgical factors of manufacturing techniques; and technological problems and measures for environmental pollution in the special steel plants.

\section{iv. Steel Plates and Sheets Division}

Blooming and Slabbing, Plates, Hot Strip, and Cold Strip Subdivisions compose the Steel Plates and Sheets Division. The Blooming and Slabbing Subdivision investigated and exchanged views on the existing status of utilization of computers at slabbing mills and metallic recuperators of soaking pits in each firm and examined measures to improve working ratio efficiency and management methods of various units. The Plates Subdivision investigated and discussed plate inspection techniques, actual status of CC slab, and operation and yield of various facilities. Further, editorial preparations are being carried on Special Report of Plates Subdivision.
The Hot Strip Subdivision deliberated on slab management system and coil management system. Papers were submitted on measures for roll adjustment and improvements on coils. The Cold Strip Subdivision made investigations on the personnel requirement and economical use of power and examined facilities to treat waste liquid and acid and remodelling of them. Both of the Hot Strip and Cold Strip Subdivisions are proceeding with editorial preparations of Thin Plate Manual which would be completed by 1972 .

\section{v. Sections and Wire Rods Division}

This division has three subdivisions; Large, Medium and Small Sections, and Wire Rods.

The Large Rods Subdivision conducted the examination of measures for quality and yield improvements. The division investigated the present situation of hot shear, cooling bed, reforming works, and descaling. It is also preparing a special report to be published in 1972. The Medium and Small Sections Subdivision examined the yield management and the improvement measures, they also studied problems and measures for air pollution and investigated soaking pit and auxiliary facilities. The Wire Rods Subdivision discussed the personnel placement problem and improvements in quality and efficiency of products. It also studied water cooling of wire rods, entrance and exit guides, and boundary works. The subdivision has compiled and published Wire Rods Manual and Sections Manual.

\section{vi. Steel Pipe and Tube Division}

Seamless Pipe Subdivision and Welded Pipe Subdivision selected the following subjects as their common themes. Those are process control, equipment control, and coating. Further discussions on management of environment (particularly noise, waste acid treatment) and matters related to shipping such as packing, bundling, marking, length measurement, and weight measurement are planned. The Seamless Pipe Subdivision discussed the elimination of glass from hot extrusion material, various factors influencing crop length in a drawing roller in relation to Mannessmann equipment, NDI precision assurance for cold rolled products, inner surfaces of Prag mill and Mandrell mill, outline of facilities for Andrel mill, and production processes of Mandrel bar.

The Welded Pipe Subdivision made studies of changes in mechanical properties due to pipe-making, flying cut-off, roll shift in spiral pipemaking, facilities and personnel requirements. Shipping Method Investigation Subcommittee has obtained sufficient data for thin pipes with large diameter during transportation with acceleration. A draft for "Recommended Specification" concerning layer-loading is beeing compiled and the special report is planned to be published early 1972 by the committee.

\section{vii. Rolling Theory Division}

The activities of this division included energetic discussions on shape control of hot rolled plates, roll board in cold rolling, surface and lubrication, metal flaws at Mannessmann driller (the model experiment by Plasticin), an analysis of shape steel rolling in model 
experiments, and mill properties of various mills. A joint experiment on shape change resistance in cold rolling has been continuously carried since the previous year. Experiments using common test pieces were completed and experiments on various steel types are currently conducted by participating companies.

\section{viii. Facilities Research Division}

Problems about iron and steel carriers were studied and discussed since the previous year. A specific emphasis was placed on LASH SYSTEM which is receiving a wide attention from concerned circles as a new main transportation method succeeding a container carrier. Results of such investigations were compiled and reported at the spring meeting of the division. The division selected "Examination of Harbor Facilities for Raw Materials of Iron and Steel in the 1970's" as a new theme. As the first step of this study, the division is compiling basic source materials on "Studies of Facilities Related to Pollution and Its Prevention in Shipping and Unloading Raw Materials".

\section{ix. Heat Economy Technique Division}

Following the previous year, the division conducted studies on smoke prevention in industrial kilns and ovens, improvements on furnace facility method, and the examination of energy control. Refractory Materials Subdivision continued the examination of problems of recuperators in reheating furnace and soaking pit. The study would soon be completed since the subdivision already began the last stage of compilation. It plans to carry further energetic activities by restructing the organization. Reheating Furnace Subcommittee terminated the activity in June, 1971 by publishing its record of research activities titled "Heat Transmission of Steel Piece Experiment and Calculation in Continuous Reheating Furnace ".

\section{x. Instrumentation Division}

In addition to the activities of the division itself, studies are conducted by Weighing and Measuring Subdivision and a number of subcommittees.

The division held three research meetings where steel producers and weighing and measuring appliance makers presented the results of research concerning measuring methods, the development of inspection terminals, utilization of computer, new measuring instruments developed by the makers. The meetings covered issues relating to processes from ironmaking to products. Subcommittees on Converter and EGS System Measuring Instrument and Load Cell for Hot Rolling compiled research results and completed their activities while the Subcommittee on Thickness Measurement by X-ray and Examination committee on the Changes in Temperature Scale Standards are collecting problems and demands from various companies.

The Weighing and Measuring Subdivision presented research results, including those of makers of weighing and measuring instruments, concerning all aspects of weighing and measuring of iron and steel and placed a particular emphasis on conveyor scale and electronic instruments. Further, the division itself is making preparations to hold its 50th anniversary meeting three times in 1972.

\section{xi. Quality Control Division}

The division has been holding 2 meetings each year. Last year the common themes of study were "Present Status of Quality Control System" and "Problems and Measures for Quality Control at Boundary Divisions between Plants (or between Works)". In addition, research papers were presented on the control of external order, autonomous control activities, quality control and computer, and methods and examples of manual control. A special report titled "Report of Inspection Team on autonomous Control by Iron and Steel Industries in the United States" was submitted. xii. Plant Engineering Research Division

The division is composed of Iron and Steelmaking Facilities and Rolling Facilities Subdivisions. The Iron and Steelmaking Facilities Subdivision, in joint efforts of iron and steel producers and machinery producers, examined the following items: furnace body supporting methods of large blast furnace ; mechanization of furnace surroundings; standardization of pulley sizes for belt conveyors and automation of unloader ; stacker and reclaimer in connection with ironmaking facilities and maintenance of steelmaking crane; brick loading of converter; the economical use of power in ingot-making process ; problems involved in designing a large converter, and the converter cooling in connection with steelmaking.

The Rolling Facilities Subdivision together with iron and steel producers and machinery makers are hoping that these joint efforts of research and exchange of views would be effective in solving problems, improving efficiency and designing most appropriate facilities for the industries for the subsequent items: concerning hot rolling facilities, a roller table, mill spindle, and coupling, oil pressure facilities, rolling roller bearing, bulb for cooling water, and the maintenance ; concerning the facilities for thick plate, a roller table, roller bearing in rolling, hot leveller, heat treatment oven, and the maintenance.

\section{xiii. Atomic Energy Division}

Within the Atomic Energy Division, System Subdivision, five subdivisions, and three subdivisions for conducting experiments are continuing research activities. Since its inauguration in September, 1970, the System Subcommittee has made a comprehensive examination on the total system, the development schedule, balance between energy and materials, and the estimation of development cost of ironmaking process utilizing atomic energy. It is examining the productivity of an ironmaking plant of $10000000 \mathrm{t} / \mathrm{yr}$ utilizing atomic energy from the economical point of view.

After an investigation on the change in the process in iron- and steel-making by utilizing electric power generated by reactor, the first Subdivision examined the economic and technical merits owing to the change in the process in heating for rolling steels. On the basis of the results of the above examination, the subdivision is making economic evaluations of a model plant with $10000000 \mathrm{t} / \mathrm{yr}$ productivity, which con- 
sists of concerned processes only and is equipped with an atomic power plant. The production processes included in the above examination are firstly, electric ironmaking $\rightarrow$ electric steelmaking $\rightarrow$ rolling (electric reheating) and secondly, (reduced iron) $\rightarrow$ electric steelmaking $\rightarrow$ rolling (electric heating).

A working group of second Subdivision is conducting the investigation on a high temperature fluid layer method which has been considered as a useful one together with shaft furnace method as a direct ironmaking method using atomic energy. Concerning the shaft furnace method, Shaft Furnace Committee continued a small scale experiment with a subsidy from the Ministry of International Trade and Industry in 1970. The experiments was conducted mainly on the reduction of iron ores by a mixed gas, $\left(\mathrm{H}_{2}+\mathrm{CO}\right)$, last year.

The third Subdivision has been studying technological problems and measures for them in two working groups, namely those for the evaluation and the safety of high temperature gas furnace for ironmaking. The detailed analysis will be conducted in close cooperation with Japan Atomic Energy Research Institute and other related organizations.

In connection with the safety of ironmaking plant using atomic energy including a high temperature gas furnace, Atomic Power Safety Research Institute is currently examining the safety of high temperature gas furnace itself. When results of such examination become available, the subdivision would begin studies on safety of ironmaking plants using atomic energy.

The fourth Subdivision picked out many problems, concerning the heat exchange with helium in a high temperature gas furnace, such as hydrogen permeation, refractory metal materials, and the structure of large heat exchanger. In order to solve problems of hydrogen permeation, hydrogen exclusion, characteristics of heat transfer between helium and steam, the subdivision established a schedule for experiments using a small size He loop (He temperature: approximately $1000^{\circ} \mathrm{C}$ ). For the purpose of carrying out the experiment schedule, Heat Exchange Subcommittee was established which is currently manufacturing the equipment for the experiment receiving a subsidy from the Ministry of International Trade and Industry. The subdivision itself is continuing the examination of practical problems of the heat exchange method including the structure, the materials, and the size.

The fifth Subdivision made a comparative examination prospects and economy of raw materials supply for various production methods of reduced gas and concluded that it is necessary to do the development study of the reduction gas production processes from heavy oil. On the basis of the above conclusion, a plan for the experiment was made. Reduction Gas Subcommittee established to execute this experimental project is manufacturing the equipment for the experiment, with also the subsidy from the Ministry of International Trade and Industry. Incidentally, Patent Group contributed a great role at the time of making contracts among participating companies necessary to carry out a joint research of the project. The Atomic Energy Division maintained its activities for three years since its establishment and contents of studies carried by each subdivision are getting enriched every year. On the other hand the investigations partly have already reached their limitations, and therefore, the experimental results being carried by the Shaft Furnace Committee and those to be carried by the Heat Exchange Committee and the Reduction Gas Committee are awaited to make a further advance in research and development of ironmaking processes using atomic energy.

\section{xiv. Iron and Steel Analysis Division}

Iron and Steel Analysis Division is consisted of Chemical Analysis, Emmission Spectro Scopic Analysis, Fluorescent X-ray Analysis, and Nonmetallic Inclusions Analysis Subdivisions. The division held two meetings of research presentation by each subdivision last year. Further, participating members exchanged the source materials on the organizations in the field of analysis.

The Chemical Analysis Subdivision conducted five research meetings and it is proceeding with the examination of analysis methods for iron and steel. It made also a draft amendment for JIS on the analysis of in steel. In addition, it made a joint research on the determination of in steel, ISO method, and Atomic Absorption Spectro Scopic Method, and also examined a draft for JIS for determining Se in iron and steel.

The Emmission Spectro Scopic Analysis Subdivision held two subdivision and two subcommittee meetings and compiled a draft paper on results of a joint experiments concerning the standard samples of Japanese iron and steel to publish it in the Journal of the Institute. It also made an experiment to investigate the effect of coexisting elements on the analytical results and compiled questionnaires on the maintenance of instruments and the trace elements analysis.

The Fluorescent X-ray Analysis Subdivision held two subdivision meetings and five subcommittee meetings, and compiled a new draft for JIS about fluorescent X-ray analysis for iron and steel. The subdivision made standard test samples and run a joint experiment concerning supplementary coefficients, $A_{\mathrm{ij}}$.

Analysis Subdivision for Non-Metallic Inclusions called four meetings and reported the experimental results on $\mathrm{Fe}-\mathrm{C}, \mathrm{Fe}-\mathrm{Mo}-\mathrm{C}$, and $\mathrm{Fe}-\mathrm{Cr}-\mathrm{C}$ alloy systems in connection with quantitative extraction method for carbides in steel.

\section{Joint Group for Basic Research of Iron and Steel}

Within this research group, jointly managed by the Japan Institute of Metals and Japan Society for Promotion of Science, three divisions terminated their activities while two other divisions were newly established in 1971. Activities are presently carried by five divisions as a result. Major activities of these divisions are described below.

\section{i. Molten Iron and Molten Slag Division}

Since the establishment of Molten Steel and Molten 
Slag Division in 1965, five subdivisions have been created so far to measure physical properties of molten metal and slag such as heat of mixing, heat of formation, specific heat, viscosity, density, diffusion coefficient, vapour pressure, and surface tension and to establish measuring methods.

Since the initial objectives have been achieved, a joint report meeting for the presentation of research results by each subdivision is to be held in January, 1972 before terminating its activities. The division is also compiling a data book on physical properties of molten steel and molten slag emphasizing research results of the division and including other research results from both the Japanese and foreign sources. The book will be published in January, 1972. (Division Chairman: Tsunezo Saito, Tohoku University)

\section{ii. Strength and Ductility Division}

Under the chairmanship of Professor Araki (The University of Tokyo), the division in its third year succeeded to make a crack forming equipment with a special research fund for the year of 1970 and persons in charge reported the results of various experiments in four meetings. Further, as a part of its activities, the division held the Second Symposium on " Strength and Ductility of Iron and Steel " in spring and a joint symposium with the Japan Institute of Metals in fall last year.

\section{iii. Solid Mass Analysis Division}

This division originally conducted its activities as a consultative body within the Pure Iron Division which was dissolved in June, 1971. It was re-established as a division and started activities in a wider field by changing its themes and principles. Although the solid mass analysis method is the most effective one in analyzing trace elements in metals, there are numerous problems related to precision and accuracy measurements. Therefore, the division is planning to clarify various factors which create such problems and measures against them. The activities of the division include studies on another theme, analysis of the concentration distribution in the surface layer of iron and steel in depth direction by ion microanalyzer. (Division Chairman: Emiko Sudo, National Research Institute for Metals)

\section{iv. Recrystallization Division}

In 1971 the third meeting of Recrystallization Division was conducted on the theme of "Effects of Manganese, Sulfur, and Oxygen on Recrystallization Texture (deep drawability) of Low Carbon Steel Plates". A research with a speciall fund aimed to examine recrystallization phenomena in iron and steel and its industrial application and selected two specific themes, "Heterogenious Plastic Deformation of Single Crystal and Bi-crystal in Rolling and Various Phenomena in Annealing" and "Migration of Grain Boundary Accompanying with Phase Transformation of Pure Iron ". As a research topic of joint meeting of all committee members. "Effects of Copper Addition on Recrystallization and Texture Formation of Iron " was selected. Practical research methods are planned to be examined.

\section{v. Delayed Failure Division}

This division is planning to clarify the mechanism of delayed failure which is frequently found in high strength steels. Basic researches are being done to explain the behaviours of hydrogen in steel which are considered as a main cause of delayed fracture. The results of those studies are certainly valuable for the industries. In 1971, the expenditure in researches conducted by the division amounted to approximately 8 million yen and thereby energetic activities were continued.

\section{vi. Solidification Division}

The Solidification Division was established in 1971 for the purpose of conducting elementary researches to clarify factors determining the solidification structure, microscopic and macroscopic segregation, the mechanism of heat transfer in ordinary ingot-making, continuous casting and solidification processes of the other types of steels.

\section{The Other Research Committees}

The other research committees conducting joint researches are those on creep, heat resistant alloys for jet engine, continuous steelmaking, utilization of atomic reactor for testing materials, testing blast furnace, standardization, and experiment on smoke and sulphur elimination, all of which presented useful studies in respective fields.

\section{i. Creep Committee}

\section{(1) Creep Testing Subcommittee}

This subcommittee has been participating in common international tests on creep rupture since 1968 and has been conducting $100 \mathrm{hr}, 1000 \mathrm{hr}, 3000 \mathrm{hr}$, $10000 \mathrm{hr}$, and $30000 \mathrm{hr}$ tests. In 1971 it completed $10000 \mathrm{hr}$ test and submitted its report to BISRA, the sponsoring organization. BISRA, in turn, sent "BISRA Confidential Report", to the committee, a data of tests up to $3000 \mathrm{hr}$ prepared by each participating country including Japan.

(2) High Temperature Tensile Test Subcommittee

High temperature tensile tests of domestically produced heat resistant steels and alloys have been carried by the subcommittee starting in 1967. As a part of comprehensive compilation of data sheets, the subcommittee made a report on results of the 4th common high temperature tensile tests and started the 5th test.

\section{(3) Sample Subcommittee}

The Sample Subcommittee has been making statistics from the data on standard creep samples distributed by the specimen bank of the subcommittee as test results are reported back from members in change of such tests.

\section{(4) Data Sheet Subcommittee}

This subcommittee has been compiling a series of data sheets related to standardization of creep testing methods, compiling drafts for standards (JIS G 0567-1966) concerning high temperature tensile test methods of iron and steel materials, and compiling data on high temperature tensile tests. Presently, it is preparing for publication of "Data on High Temperature Strength of Metal Materials, Vol. I, Low 
Alloy Steel" as a special report of the Institute. In addition, it compiled a data at the request of the Standardization Committee of the Institute on ISO Iron and Steel Division SC 10 Subdivision to be submitted to ISO TC/17 SC10/ETPSG in cooperation with participating members.

(5) National Research Institute for Metals Creep Data Sheet Subcommittee

The subcommittee, in close communication with the National Research Institute for Metals, has selected types of steels recommended for creep rupture tests at the latter since 1966. The number of types of steels thus recommended is 34 . In the current term the subcommittee examined 5 types in B rank following 6 types previously submitted to the NRIM and selected 2 types (SUS 43 HTB, U 500) for the creep rupture test.

(6) Draft JIS Subcommittee

This subcommittee was newly established in 1971 and (1) composed drafts for JIS for creep rupture testing methods and (2) conducted basic investigations and study meetings concerning drafts for JIS for high temperature relaxation testing methods.

\section{ii. Research Committee on Heat Resistant Alloys for Jet Engine}

Since 1969 the committee has been conducting a common joint research to develop domestically heat resistant alloys for jet engine. In 1969 it constructed two units of new fatigue testing machine with 10000000 yen subsidy from MITI for development of important technology. In 1970 the committee started preliminary tests on the testing machines as well as comparative tests with existing machines. During the tests it made special efforts to carry thermal fatigue tests in wider fields so as to meet practical conditions of jet engines in use. The experiments were completed late March, 1970. In 1971 it carried thermal fatigue tests of various materials using the testing machine in order to improve qualities of heat resistant alloys and to establish production methods.

\section{iii. Continuous Steelmaking Research Committee}

In connection with experiments of a triple-stage continuous steelmaking method, the committee assisted NRIM in technological aspects. In 1970 it expanded the molten hot water supply equipment and extended the testing period to two hours. Further, it clarified various features of a continuous steelmaking method and is compiling sufficient basic data required for practical application of the method.

\section{iv. Joint Committee on Iron and Steel Irradiation Tests}

Using the material testing reactor installed at Japan Atomic Energy Research Institute which began operations in 1969, the committee made irradiation tests on iron and steel materials during the first year designated as a test period. It is presently compiling the results of such tests.

\section{v. Testing Blast Furnace Committee}

Activities of this committee included a large scale repairing and remodelling of the equipment such as construction of two units of pebble type hot blast furnace and the extension of the furnace height by one meter and preparatory operation was conducted twice last year (in March and August).

During the 21 st operation, high temperature hot blast and charging of natural gas enabled to clarify the role of hydrogen in the mechanism for lowering coke ratio and reduction mechanism. The 22nd operation clarified the effect of coke with low reactivity on coke ratio and reduction reactions in a test using petroleum coke.

\section{vi. Standardization Committee}

The committee, which consists of two divisions and eighteen subdivisions, is compiling and rechecking drafts for JIS on iron and steel and those related to iron and steel and is positively participating in examination and presentation of comments on ISO iron and steel standards and preparation of data sheets.

(1) ISO Iron and Steel Division

Totally 24 persons participated in international conferences of SC-2 (classification of steel), SC-4 (hot treated steel), SC-8 (sizes of steel products), SC-10 (steel for pressure containers) and SC-12 (thin plate, zinc plate) of ISO TC-17 (steel) to reflect Japanese views. The division further investigated and examined ISO drafts on 49 items including 24 steel standards, 10 standards on size, and 15 standards on testing and analysis methods and made comments on them. It decided to positively participate in ISO on rail and oil pipes as a $\mathrm{P}$ member and in relation to this decision, three subdivisions of SC-2 (classification of steel), SC-15 (rails) and TC-67 (oil pipes) were newly established.

\section{(2) Data Sheet Division}

The division made joint experiments on test materials of $25 \mathrm{~mm}^{\phi}, 50 \mathrm{~mm}^{\phi}$, and $100 \mathrm{~mm}^{\phi}$ of two types of steels, SCM 3 and SCM 22, following similar experiments on SC materials to measure yield strength, tensile strength, elongation, reduction in area, Charpy impact values of $2 \mathrm{mmU}$ and $2 \mathrm{mmV}$, hardness in cross section, hardness after tempering, and grain size, and compiled data on mechanical properties in consideration of mass effects of chromium molybdenum steel. Publication of the test results is forthcoming. The division is planning to compile data sheets on six steel types of SCr 4, SCr 22, SMn 3, SMnC 21, SCM 4, and SCM 21 during the coming year.

In cooperation with the Creep Committee, the division made high temperature tensile tests on 24 types of steels including 5 types each of SM and SPV materials, 6 types of SB materials, 4 types each of STPT materials and STS materials. The division completed data sheets about relations between lower yield strength or $0.2 \%$ offset yield strength, tensile strength, elongation, reduction in area, (lower yield strength or $0.2 \%$ offset yield strength)/(tensile strength at room temperature) and temperature ranging from room temperature to $700^{\circ} \mathrm{C}$. Currently preparations of the data sheets are made for future publication. (3) Seven standing subdivisions including Plain Carbon Steel Subdivision re-examined eighteen JIS standards, and composed draft amendments for seventeen pipe standards. They also composed six drafts for JIS including Cr-Mo steel plates for pressure 
vessels, bolt materials for high temperature use, alloy steel rod for bolts in special purpose, and Se analysis method.

Mechanical Test Subdivision is carrying preparatory experiments for the purpose of manufacturing standard-test pieces for adjusting Charpy impact testing machine.

\section{vii. Smoke and Soot Elimination Test Committee}

As a part of control of the environment, this committee was established in December 1970 to run experiments with regard to practical utilization of the equipment to decrease sulfurdioxide in waste gas of a sintering furnace. Ten makers having blast furnace, the Institute, and The Japan Iron and Steel Federation are members of the committee. The total cost of experiment is 1600 million yen. In conducting the experiment, the committee selected the main theme entitled "Experiment of Circulation Process to Exclude Sulfur Dioxide in Waste Gas of Sintering Plant by Utilizing Ammonium in Coke Oven Gas with the Aim of Its Industrialization " and received 105 million yen subsidy from MITI for development of important technology. Test facilities are presently constructed at Keihin Works of Nippon Kokan and test results will be available in 1972 .

\section{Outlook for 1972}

Industrial Structure Council announced in May in 1971 its interim report entitled "Basic Directions of Commercial and Industrial Policies for 1970's". According to the report, the 1970's will be a new era of development which is different from that of economic recovery and growth as our country experienced in 25 years post-war period. The country overcame double tasks of an under developing and poorly vanquished nation. Its economy has tremendously improved as indicated by the fact that exports in 1949, the year in which 360 yen per dollar rate was established, amounted to merely 500000000 dollars while today it exceeds 200000 million dollars. During the period, the country emphatically pushed the policy of developing heavy and chemical industries, promoted heroes of exports such as the iron and steel industry and shipbuilding industry, and achieved the "miracle of the Japanese economy" so named by Western nations. Such a rapid growth, however, invited criticisms of foreign countries and has stimulated an attitude of protective trade internationally as exemplified by the U.S. surcharges on imports. Within the country, destruction of our environment has began to draw much attention, too.
In these circumstances many people began to favour a switch in the Japanese economic policy from "Achievement of Growth" to "Utilization of Development". Today, in order to keep favourable environment and to prevent industrial hazards, efforts are made to alter the main stream of policy from "production first and priority in economic growth" to a balanced growth and protection of the people's living conditions.

In the iron and steel industries, even major blast furnace producers could not escape the recession in their business and many companies had to decrease the dividends in 1971. In short, the industries are facing a critical trial today. Expenditure on prevention of environmental pollution is not directly connected with production but it is not a small sum. The enormous cost, together with changes in situations surrounding the exports, presents a serious problem for the industry. The trial has to be overcome in order to accomplish a new stage of development. The severer the trial, the larger the development would be. Considering the stages the Japanese iron and steel industries have passed, the first generation is characterized by ancient ironmaking method, the second generation by the dawn of modern iron and steel industries during the late Edo period and the Meiji era and the third generation by the accomplishment of blast furnace and converter methods which led the rapid development in the postwar period, The present period is the time awaiting the birth of the fourth generation.

The task of the iron and steel industry today is to cultivate technology for the fourth generation. Such a task requires conscientious efforts of the industry in consolidation of anti-pollution technology for which positive actions have been carried in recent years and decisive solutions for technical problems by developing outstanding new technology such as direct ironmaking and ironmaking using nuclear energy.

In the structure of exports, quantitative expansion of products is not the only requirement in the future. Rather, the industry should endeavour for qualitative expansion such as promotion of outward introduction of technology by fully utilizing the internationally appreciated advanced technology.

Before concluding, my sincere thanks are extended to Messrs. Yoshihiro Adachi, Koki Osone, Koshiro Mizuno, Teruhisa Uehara, Yoichi Enomoto, Hideo Otsubo, Haruo Okamoto, Mamoru Kamishita, Tadao Kokawa, Takeomi Kobayashi, and Masanori Yazaki who have rendered kind cooperation in preparation of this review. 